\title{
On the spotless mind
}

Miguel Leal Rato, MD

Neurology ${ }^{\circledR}$ 2018;91:977. doi:10.1212/WNL.0000000000006556

\section{Correspondence}

Dr. Leal Rato

mlealrato@gmail.com

The tilting of the head

MORE ONLINE

and the vacant eyes

and then the most wonderful surprise

ค Audio

as you laugh it off and try

to disguise that you have no idea

who I am or why you're here

in front of me with a daughter by your side

who says you've dwindled away

until there is nothing left of you

that you leave the stove on

and forget to water the chrysanthemum

so you laugh it off

because she thinks she knows it all

as you cover the burns on your hand

and stare blankly at me

for I asked a rather peculiar question

Do you know where you are?

You tilt your head

searching with vacant eyes

and then the most wonderful surprise

as you notice for the first time

the white coat

and the stethoscope

so you laugh it off because

it's the doctor's office of course

but you have no idea

who I am or why you're here

in front of me with a daughter by your side

who says you've been failing

And so she cries

You wait dazed and amused

for it makes no sense

nothing has for a while

the days just blend together

fading one into another

but you laugh it off

stop your hands from shaking

and with a soft touch grab your daughter's thigh

worry not, my child, the doctor's here

besides there is nothing wrong with me

I'm getting old and

you know

some things just have to be so. 


\title{
Neurology
}

\author{
On the spotless mind \\ Miguel Leal Rato
}

Neurology 2018;91;977

DOI 10.1212/WNL.0000000000006556

\section{This information is current as of November 19, 2018}

\section{Updated Information \&} Services

\section{Subspecialty Collections}

Permissions \& Licensing

Reprints including high resolution figures, can be found at: http://n.neurology.org/content/91/21/977.full

This article, along with others on similar topics, appears in the following collection(s):

All Cognitive Disorders/Dementia

http://n.neurology.org/cgi/collection/all_cognitive_disorders_dementia Assessment of cognitive disorders/dementia

http://n.neurology.org/cgi/collection/assessment_of_cognitive_disorder s_dementia

Clinical neurology examination

http://n.neurology.org/cgi/collection/clinical_neurology_examination Clinical neurology history

http://n.neurology.org/cgi/collection/clinical_neurology_history

Information about reproducing this article in parts (figures,tables) or in its entirety can be found online at:

http://www.neurology.org/about/about_the_journal\#permissions

Information about ordering reprints can be found online:

http://n.neurology.org/subscribers/advertise

Neurology ${ }^{\circledR}$ is the official journal of the American Academy of Neurology. Published continuously since 1951, it is now a weekly with 48 issues per year. Copyright () 2018 American Academy of Neurology. All rights reserved. Print ISSN: 0028-3878. Online ISSN: 1526-632X.

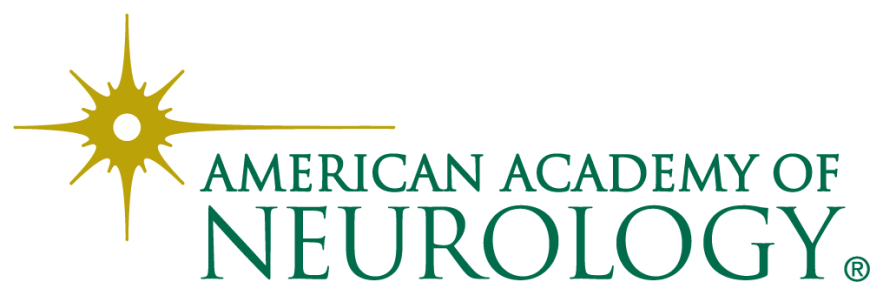

